\title{
(6) OPEN ACCESS \\ Do state minimum markup/price laws work? Evidence from retail scanner data and TUS-CPS
}

\author{
Jidong Huang, ${ }^{1}$ Jamie F Chriqui, ${ }^{2}$ Hillary DeLong, ${ }^{1}$ Maryam Mirza, ${ }^{3}$ Megan C Diaz, ${ }^{3}$ \\ Frank J Chaloupka ${ }^{1,3}$
}

- Additional material is published online only. To view please visit the journal online (http://dx.doi.org/10.1136/ tobaccocontrol-2016-053093).

${ }^{1}$ School of Public Health, Georgia State University, Atlanta, USA

${ }^{2}$ Division of Health Policy and Administration, School of Public Health, University of Illinois at Chicago, Chicago, Illinois, USA

${ }^{3}$ Department of Economics, University of Illinois at Chicago, Chicago, Illinois, USA

\section{Correspondence to} Dr. Jidong Huang, School of Public Health, Georgia State University, 140 Decatur St. Atlanta, GA 30303, USA; jhuang17@gsu.edu

Received 31 March 2016 Revised 21 June 2016 Accepted 23 June 2016

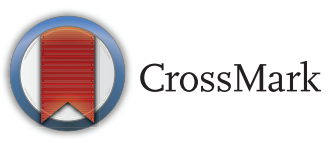

To cite: Huang J, Chriqui JF, DeLong $\mathrm{H}$, et al. Tob Control 2016;25:i52i59.

\section{ABSTRACT}

Background Minimum markup/price laws (MPLs) have been proposed as an alternative non-tax pricing strategy to reduce tobacco use and access. However, the empirical evidence on the effectiveness of MPLs in increasing cigarette prices is very limited. This study aims to fill this critical gap by examining the association between MPLs and cigarette prices.

Methods State MPLs were compiled from primary legal research databases and were linked to cigarette prices constructed from the Nielsen retail scanner data and the self-reported cigarette prices from the Tobacco Use Supplement to the Current Population Survey. Multivariate regression analyses were conducted to examine the association between MPLs and the major components of MPLs and cigarette prices.

Results The presence of MPLs was associated with higher cigarette prices. In addition, cigarette prices were higher, above and beyond the higher prices resulting from MPLs, in states that prohibit below-cost combination sales; do not allow any distributing party to use trade discounts to reduce the base cost of cigarettes; prohibit distributing parties from meeting the price of a competitor, and prohibit distributing below-cost coupons to the consumer. Moreover, states that had total markup rates $>24 \%$ were associated with significantly higher cigarette prices.

Conclusions MPLs are an effective way to increase cigarette prices. The impact of MPLs can be further strengthened by imposing greater markup rates and by prohibiting coupon distribution, competitor price matching, and use of below-cost combination sales and trade discounts.

\section{INTRODUCTION}

Substantial research has demonstrated that increasing cigarette taxes is one of the most effective ways to reduce cigarette consumption; ${ }^{1}$ however, the impact of raising cigarette taxes can be diluted through the tobacco industry's discounting and promotional tactics, particularly in states where cigarette price regulations do not address cigarette sales prices. The tobacco industry's price-reducing tactics diminish the impact of increasing cigarette taxes, and for price-sensitive smokers, such as pricesensitive youth and low-income smokers, who are more likely to take advantage of discounting programmes, these tactics can be detrimental to pricebased tobacco control efforts. ${ }^{2-4}$ While raising state cigarette taxes further can mitigate the negative impact of the industry's price-reducing tactics, in many cases it is not politically feasible to do so due to a lack of political will, along with supermajority voting requirements for tax measures and gubernatorial veto power, as well as threats from the tobacco industry to force tax measures to a ballot measure. ${ }^{5}$ It was within this context that the tobacco control community advocated non-tax pricing measures, such as minimum markup/price laws (MPLs), as an alternative to cigarette tax increases. ${ }^{56}$

MPLs emerged in the USA in the mid-20th century, ${ }^{7}$ and were originally implemented to protect small businesses from the unfair sales tactics of larger competitors ${ }^{8}{ }^{9}$ rather than to bolster tobacco control or protect state tax interests. The effect of these laws was not truly felt until the 1980s, when tobacco manufacturers began introducing price-reducing mechanisms, such as couponing and multipack discounts, in an effort to minimise the impact of price increases on price-sensitive smokers. ${ }^{10}$ The use of these mechanisms spread with additional Federal tax increases, the introduction of the Master Settlement Agreement of $1998^{11}$ and the continued rise in cigarette prices throughout the 1990s and early 2000s. ${ }^{12}$ At a base level, pricing laws prohibit the intentional injury of competitors through price cuts, and can impose both civil and criminal penalties for violations. ${ }^{13}$ Pricing laws fall into two main categories: (1) those that require a statutory markup to be applied to the base cost of wholesalers and/or retailers (hereafter 'minimum markup'); and (2) those that simply prohibit sales of products below actual cost (hereafter 'minimum price'). ${ }^{14}$ While most pricing laws regulate cigarettes or tobacco products explicitly, several states (eg, California, Hawaii, Colorado ${ }^{15}$ ) have applied more general pricing laws to tobacco sales through agency opinions or state-level courts. Both types of laws use a base cost of cigarettes, which can be defined in a variety of ways, including manufacturer's list price, invoice cost or purchase price. Minimum markup laws require one or more levels of the distribution chain to apply a markup percentage to this base cost, meant to represent a presumed cost of doing business. ${ }^{716}$ In addition to the markup, these laws also often require the application of excise taxes (Federal, state and/or local), cartage costs (where incurred) or other fees to the base cost. ${ }^{16}$ Minimum price laws function similarly to markup laws; however, the definition of 'cost' tends to be less formulaic; there is no established markup applied, and they are often silent to the application of taxes, cartage or fees. Fewer states use this method than minimum markup laws. ${ }^{14}$ In addition to establishing a minimum sales price, these laws also often regulate mechanisms that can work to decrease established prices, including trade discounts, price-matching, multipack discounts and coupons. 
To what extent MPLs can reduce cigarette consumption depends on whether such laws increase retail cigarette prices, particularly the prices of non-premium cigarettes. Empirical evidence on the effectiveness of MPLs is limited. The results from two early studies were mixed at best. Feighery et al examined a sample of eight US states with MPLs and seven states without MPLs, and concluded that average cigarette prices were not significantly different between the two groups. However, they did find that New York, which had stronger MPLs that banned price promotions from being considered in the minimum price calculation, had higher average cigarette prices. ${ }^{17}$ Tynan et al ${ }^{18}$ examined Nielsen retail scanner data and found that average cigarette prices were lower in states with MPLs. Our paper builds on these two studies and expands this literature by examining, instead of average cigarette prices, the low-priced cigarettes using Nielsen retail scanner data. Unlike Tynan et al, who used data from all 52 Nielsen markets, the majority of which cross state boundaries, we focused our analysis on a subset of Nielsen markets that do not cross state boundaries in an effort to reduce the measurement errors. To overcome the limited number of states in analysing Nielsen retail scanner data, and to corroborate our findings, we also conducted analysis linking MPLs with self-reported prices using the data from the Tobacco Use Supplement to the Current Population Survey (TUS-CPS). More importantly, we analysed not just the presence of MPLs, but also the main components present within state minimum markup/price laws.

\section{METHODS}

\section{Data sources}

Minimum markup/price laws for each of the 50 states and the District of Columbia (hereafter referred to collectively as 'states') from 2006 to 2014 were compiled through primary legal research databases available through commercial legal research service providers, Lexis-Nexis and Westlaw. Relevant state laws were identified through Boolean keyword searches conducted for each state and were limited to each state's statutes and regulations, case law, Attorney's General (AG) opinions and Department of Revenue notices/rulings. Collection was focused on laws that specifically related to the pricing of cigarettes or tobacco products. State regulations establishing general pricing laws were included where agency opinions, rulings or case law specifically applied them to tobacco products; those without specific ties were excluded from collection. Similarly, state laws invalidated by case law or AG opinions were excluded. Publicly available secondary sources, such as information from state department of revenue or taxation websites, published articles and state reports, were used to verify initial collection results and clarify ambiguities. ${ }^{19}$ Additionally, ambiguities regarding California and Idaho's respective pricing laws' applicability to tobacco were clarified by directly contacting state enforcement agencies.

Cigarette price data used in this study were compiled from two different sources: retail scanner data from the Nielsen Company and TUS-CPS. The Nielsen retail scanner data contain quarterly product and market level cigarette sales and price data from 2007 to 2014, collected from Nielsen participating retail stores, which include food, drug and mass merchandise stores, as well as convenience stores. A Nielsen market consists of groups of counties centred on a major city. In many cases, counties in the same Nielsen market belong to different states, as a Nielsen market can cross state borders and cover areas in two or multiple states. To reduce the measurement errors in measuring state level prices, we decided to focus our analysis on 19
Nielsen markets that fall completely within a state boundary (see table 1 for the complete list of these 19 markets). Since the price data were not provided to us in one market for two years, our total number of data points was 600 (19 markets $\times 8$ years $\times 4$ quarters minus 8 ). We also conducted sensitivity analysis by including three additional Nielsen markets that had at least $80 \%$ of its population resident in one single state. In addition, a sensitivity analysis that includes all 52 Nielsen markets, similar to those in Tynan et al, was also conducted.

The CPS was conducted by the Bureau of Labor Statistics through telephone and face-to-face interviews. Every month the CPS surveys a sample of $\sim 60000$ households to collect a wide range of demographic, labour force and household characteristics. Data on special topics are also gathered from these same respondents in periodic supplemental surveys, including the TUS. Seven waves of the TUS have been sponsored by the National Cancer Institute (NCI) starting in 1992. We use the two most recent waves 2006-2007 and 2010-2011 for this analysis, given the availability of MPL data. Our sample consisted of 40838 self-responding smokers aged 15 years and older who resided in the continental USA, who reported the prices that they paid in their last purchase of cigarettes. Proxy respondents were allowed in TUS-CPS, but we excluded those respondents because they were not asked the full range of smoking questions, including some key cigarette price questions. When analysing TUS-CPS data, we controlled for individual level demographic characteristics, including gender, age, race, Hispanic ethnicity, education, real family income and employment/labour force participation. Online supplementary appendix tables S1 and S2 provide descriptive statistics for the Nielsen and TUS-CPS samples, respectively.

\section{Measures}

MPL measures: A series of dichotomous and categorical measures were created to capture the presence and components of the MPLs. A dichotomous measure captured the presence of MPLs in a state. Additionally, separate variables were constructed to reflect MPL components: (1) the number of distributing parties subject to MPLs (a score of $1=2+$ regulated parties; $0=1$ or no regulated parties); (2) an ordinal measure, as well as five dichotomous variables, of the total markup percentage across the standard distribution channel $(0=$ zero markup, $1 \geq 0-6 \%$ markup, $2 \geq 6-12 \%$ markup, $3 \geq 12-18 \%$ markup, $4 \geq 18-24 \%$ markup, and 5 $\geq 24 \%$ markup); (3) whether cartage is applied to the base cost $(1=$ yes, $0=$ no $)$; 4) whether excise taxes are applied to the base cost $(1=$ yes, $0=$ no); (5) whether any other fees or taxes (non-excise) are applied to the base cost $(1=$ yes, $0=$ no); (6) whether the state permits the use of coupons that lower the price below statutory minimums $(1=$ does not allow, $0=$ allowed or silent); (7) whether any type of vendor may distribute below-cost coupons to the consumer ( $1=$ not allowed, $0=$ allowed); (8) whether combination sales (eg, buy-one-get-one/multipack, cigarette and other tobacco products and tobacco and non-tobacco) are permitted where they reduce the price below cost $(1=$ not permitted, $0=$ permitted); (9) whether trade discounts may be used by any distributing party to reduce the base cost of cigarettes $(1=$ not allowed, $0=$ allowed); (10) whether trade discounts are defined to include discount programmes such as master-type plans or buydowns ( $1=$ not included/defined/used to reduce cost, $0=$ included $) ;(11)$ whether distributing parties may meet the price of a competitor $(1=$ may not meet/state silent, $0=$ may meet). Additionally, we created two composite dichotomous index measures that captured the aspects of MPLs related to restrictions applied pre-sale ( $1=$ yes if trade discounts are not allowed to be used by any 
Table 1 Nielsen markets included in analysis

\begin{tabular}{|c|c|c|c|c|c|c|}
\hline Market & State & $\begin{array}{l}\text { Per cent of population } \\
\text { within state }(\%)\end{array}$ & $\begin{array}{l}\text { Minimum price/markup } \\
\text { laws }\end{array}$ & Store types & 19 market sample & 22 market sample \\
\hline Baltimore & MD & 100 & Yes & FDM & 1 & 1 \\
\hline Birmingham & $\mathrm{AL}$ & 100 & No & $\mathrm{CV}+\mathrm{FDM}$ & 1 & 1 \\
\hline Buffalo-Rochester & NY & 86 & Yes & FDM & 0 & 1 \\
\hline Columbus & $\mathrm{OH}$ & 100 & Yes & FDM & 1 & 1 \\
\hline Dallas & TX & 92 & No & $\mathrm{CV}+\mathrm{FDM}$ & 0 & 1 \\
\hline Des Moines & $\mathrm{IA}$ & 100 & Yes & FDM & 1 & 1 \\
\hline Grand Rapids & $\mathrm{Ml}$ & 100 & No & FDM & 1 & 1 \\
\hline Houston & $\mathrm{TX}$ & 100 & No & $\mathrm{CV}+\mathrm{FDM}$ & 1 & 1 \\
\hline Las Vegas & NV & 100 & Yes & FDM & 1 & 1 \\
\hline Los Angeles & CA & 100 & Yes & $\mathrm{CV}+\mathrm{FDM}$ & 1 & 1 \\
\hline Miami & $\mathrm{FL}$ & 100 & No & $\mathrm{CV}+\mathrm{FDM}$ & 1 & 1 \\
\hline Milwaukee & WI & 100 & Yes & FDM & 1 & 1 \\
\hline Orlando & $\mathrm{FL}$ & 100 & No & $\mathrm{CV}+\mathrm{FDM}$ & 1 & 1 \\
\hline Phoenix & $A Z$ & 100 & No & $\mathrm{CV}+\mathrm{FDM}$ & 1 & 1 \\
\hline Raleigh-Durham & NC & 86 & No & $\mathrm{CV}+\mathrm{FDM}$ & 0 & 1 \\
\hline Sacramento & CA & 100 & Yes & FDM & 1 & 1 \\
\hline San Antonio & TX & 100 & No & $\mathrm{CV}+\mathrm{FDM}$ & 1 & 1 \\
\hline San Diego & CA & 100 & Yes & FDM & 1 & 1 \\
\hline San Francisco & $C A$ & 100 & Yes & $\mathrm{CV}+\mathrm{FDM}$ & 1 & 1 \\
\hline Seattle & WA & 100 & Yes & $\mathrm{CV}+\mathrm{FDM}$ & 1 & 1 \\
\hline Syracuse & NY & 100 & Yes & FDM & 1 & 1 \\
\hline Tampa & $\mathrm{FL}$ & 100 & No & $\mathrm{CV}+\mathrm{FDM}$ & 1 & 1 \\
\hline
\end{tabular}

$\mathrm{CV}$, convenience stores; FDM, food, drug and mass merchandise stores.

distributing party to reduce the base cost of cigarettes, trade discounts are defined not to include discount programmes, and/ or distributing parties are not allowed to meet the price of a competitor; $0=$ if otherwise) and applied at sale ( $1=$ yes if a state does not allow coupon use to reduce cost, vendors are not allowed to distribute below-cost coupons to the consumer and/ or combination sales are not permitted; $0=$ if otherwise).

Cigarette prices from Nielsen retail scanner data: The price for a pack of cigarettes for a specific brand and product type in a given market/quarter/store type was first calculated by dividing the dollar sales by sales volume for that specific brand and product type in the same market/quarter/store type. Then the prices for all cigarette brands and product types within a given market/quarter were ranked from the highest to the lowest, regardless of store types (a store type variable was included in our analysis indicating the type of stores the price was from) and the prices at the 25 th centile and 50th centile (median) were extracted and used as the cigarette price variables in the analysis. The price variables used in our analyses were adjusted for inflation using the Consumer Price Index (indexed to 1 for the last quarter of 2014) obtained from the Bureau of Labor Statistics.

Cigarette prices from TUS-CPS were the self-reported last purchase price for a pack of cigarettes. For those who reported a carton purchase, the price was converted to per pack price and an indicator of carton purchase was included in our analysis. Similarly, cigarette prices from TUS-CPS were also inflation-adjusted.

\section{Analytical model}

The following model was used to estimate the association between MPLs and cigarette prices using the Nielsen retail scanner data:

$$
\begin{aligned}
\text { CigPricemarket/quarter }= & \beta 0+\beta 1(\text { MPLs }) \\
& +\beta 2(\text { MPLs-components }) \\
& +\beta 3 \text { Taxrates }+\beta 4 \text { Year } \\
& +\beta 5 \text { Quarter }+\varepsilon
\end{aligned}
$$

CigPrice is either the cigarette price at the 25 th centile or at the 50 th centile in a given market/quarter. MPLs capture the presence of an MPL in a state. MPLs-components are the 11 major MPL components, along with two composite index dichotomous variables, discussed above. We examined each component separately because of the high collinearity among them. Taxrates are state cigarette excise tax rates. A similar model, which also controls for individual demographic characteristics, as well as survey waves, was used for TUS-CPS. This equation was estimated using ordinary least square methods with Huber-White SEs, which were clustered at the state level.

\section{RESULTS}

Table 2 presents the results examining the association between cigarette prices and MPLs in 19 Nielsen markets. Regardless of the price percentiles examined, the presence of MPLs was positively and significantly associated with cigarette prices. The results indicate that per pack cigarette prices at the 25 th centile in states with MPLs were 25-55 cents higher than those without MPLs, and cigarette prices at the 50th centile in states with MPLs were 18-52 cents higher than those without MPLs. The higher prices represent $\sim 5-11 \%$ and 3-9\% increases in prices at the 25 th and 50th centiles, respectively. The association between the presence of MPLs in a state and cigarette prices was highly significant across all MPL component model 
Table 2 Association between cigarette price and minimum price laws: results from Nielsen Retail Scanner Data 2007-2014 (19 markets) 25th price centile

\begin{tabular}{|c|c|c|c|c|c|c|c|}
\hline & (1) & (2) & (3) & (4) & (5) & (6) & (7) \\
\hline Variables & Baseline result & $\begin{array}{l}\text { Number of parties regulated } \\
>1\end{array}$ & $\begin{array}{l}\text { Total markup across } \\
\text { standard distribution }\end{array}$ & Cartage applied to base cost & $\begin{array}{l}\text { Any taxes applied to base } \\
\text { cost }\end{array}$ & $\begin{array}{l}\text { Other fees applied to base } \\
\text { cost }\end{array}$ & $\begin{array}{l}\text { State does not allow } \\
\text { coupons }\end{array}$ \\
\hline Minimum pricing law & $0.273^{* * *}(0.0267)$ & $0.463^{* * *}(0.0277)$ & $0.495^{* * *}(0.0375)$ & $0.315^{* * *}(0.0268)$ & $0.442^{* * *}(0.0290)$ & $0.282^{* * *}(0.0279)$ & $0.272^{* * *}(0.0277)$ \\
\hline $\begin{array}{l}\text { State cigarette excise } \\
\text { tax rate }\end{array}$ & $0.0113^{* * *}(0.000126)$ & $0.0125^{* * *}(0.000168)$ & $0.0113^{* * *}(0.000125)$ & $0.0112^{* * *}(0.000125)$ & $0.0118^{* * *}(0.000131)$ & $0.0114^{* * *}(0.000130)$ & $0.0113^{* * *}(0.000135)$ \\
\hline MPL-component & & $-0.404^{* * *}(0.0337)$ & $-0.122^{* * *}(0.0141)$ & $-0.434^{* * *}(0.0278)$ & $-0.331^{* * *}(0.0305)$ & $-0.0561^{*}(0.0311)$ & $0.00580(0.0343)$ \\
\hline Observations & 600 & 600 & 600 & 600 & 600 & 600 & 600 \\
\hline \multirow[b]{3}{*}{ Variables } & 0.929 & 0.940 & 0.935 & 0.936 & 0.940 & 0.929 & 0.929 \\
\hline & (8) & (9) & (10) & (11) & (12) & (13) & (14) \\
\hline & $\begin{array}{l}\text { Consumers cannot receive } \\
\text { below-cost coupon }\end{array}$ & $\begin{array}{l}\text { Below-cost combination sales } \\
\text { not allowed }\end{array}$ & $\begin{array}{l}\text { Trade discounts may not be } \\
\text { used }\end{array}$ & $\begin{array}{l}\text { Trade discount definition does not } \\
\text { include buydowns, etc }\end{array}$ & $\begin{array}{l}\text { Parties may not meet } \\
\text { competitor pricing }\end{array}$ & $\begin{array}{l}\text { Promotion restrictions } \\
\text { applied presale }\end{array}$ & $\begin{array}{l}\text { Promotion restrictions } \\
\text { applied at sale }\end{array}$ \\
\hline Minimum pricing law & $0.272^{* * *}(0.0277)$ & $0.00932(0.0299)$ & $0.253^{* * *}(0.0266)$ & $0.353^{* * *}(0.0442)$ & $0.253^{* * *}(0.0266)$ & $0.548^{* * *}(0.0546)$ & $0.278^{* * *}(0.0376)$ \\
\hline $\begin{array}{l}\text { State cigarette excise } \\
\text { tax rate }\end{array}$ & $0.0113^{* * *}(0.000135)$ & $0.0114^{* * *}(0.000129)$ & $0.0110^{* * *}(0.000123)$ & $0.0113^{* * *}(0.000128)$ & $0.0110^{* * *}(0.000123)$ & $0.0110^{* * *}(0.000123)$ & $0.0113^{* * *}(0.000135)$ \\
\hline MPL-component & $0.00580(0.0343)$ & $0.321^{* * *}(0.0276)$ & $0.295^{* * *}(0.0491)$ & $-0.0873^{* *}(0.0401)$ & $0.295^{* * *}(0.0491)$ & $-0.295^{* * *}(0.0491)$ & $-0.00580(0.0343)$ \\
\hline Observations & 600 & 600 & 600 & 600 & 600 & 600 & 600 \\
\hline$R^{2}$ & 0.929 & 0.936 & 0.932 & 0.929 & 0.932 & 0.932 & 0.929 \\
\hline \multicolumn{8}{|l|}{ 50th price centile } \\
\hline & (1) & (2) & (3) & (4) & (5) & (6) & (7) \\
\hline Variables & Baseline Result & $\begin{array}{l}\text { Number of Parties } \\
\text { Regulated }>1\end{array}$ & $\begin{array}{l}\text { Total Markup Across } \\
\text { Standard Distribution }\end{array}$ & Cartage Applied to Base Cost & $\begin{array}{l}\text { Any Taxes Applied to Base } \\
\text { Cost }\end{array}$ & $\begin{array}{l}\text { Other Fees Applied to } \\
\text { Base Cost }\end{array}$ & $\begin{array}{l}\text { State Does Not Allow } \\
\text { Coupons }\end{array}$ \\
\hline Minimum pricing law & $0.208^{* * *}(0.0263)$ & $0.424^{* * *}(0.0287)$ & $0.437^{* * *}(0.0365)$ & $0.259^{* * *}(0.0261)$ & $0.411^{* * *}(0.0293)$ & $0.219^{* * *}(0.0281)$ & $0.207^{* * *}(0.0280)$ \\
\hline $\begin{array}{l}\text { State cigarette excise } \\
\text { tax rate }\end{array}$ & $0.0114^{* * *}(0.000122)$ & $0.0128^{* * *}(0.000163)$ & $0.0114^{* * *}(0.000120)$ & $0.0113^{* * *}(0.000120)$ & $0.0120^{* * *}(0.000123)$ & $0.0115^{* * *}(0.000123)$ & $0.0114^{* * *}(0.000128)$ \\
\hline MPL-component & & $-0.460^{* * *}(0.0353)$ & $-0.126^{* * *}(0.0145)$ & $-0.524^{* * *}(0.0316)$ & $-0.398^{* * *}(0.0315)$ & $-0.0696^{* *}(0.0296)$ & $0.00624(0.0311)$ \\
\hline Observations & 600 & 600 & 600 & 600 & 600 & 600 & 600 \\
\hline \multirow[b]{3}{*}{ Variables } & 0.931 & 0.945 & 0.936 & 0.940 & 0.946 & 0.931 & 0.931 \\
\hline & (8) & (9) & (10) & (11) & (12) & (13) & (14) \\
\hline & $\begin{array}{l}\text { Consumers Cannot Receive } \\
\text { Below-Cost Coupon }\end{array}$ & $\begin{array}{l}\text { Below-Cost Combination } \\
\text { Sales Not Allowed }\end{array}$ & $\begin{array}{l}\text { Trade Discounts May Not Be } \\
\text { Used }\end{array}$ & $\begin{array}{l}\text { Trade Discount Definition Does Not } \\
\text { Include Buy Downs, etc }\end{array}$ & $\begin{array}{l}\text { Parties May Not Meet } \\
\text { Competitor Pricing }\end{array}$ & $\begin{array}{l}\text { Promotion Restrictions } \\
\text { Applied Pre-Sale }\end{array}$ & $\begin{array}{l}\text { Promotion Restrictions } \\
\text { Applied at Sale }\end{array}$ \\
\hline Minimum pricing law & $0.207^{* * *}(0.0280)$ & $-0.0717^{\star *}(0.0300)$ & $0.185^{* * *}(0.0262)$ & $0.233^{* * *}(0.0408)$ & $0.185^{* * *}(0.0262)$ & $0.522^{* * *}(0.0508)$ & $0.213^{* * *}(0.0318)$ \\
\hline $\begin{array}{l}\text { State cigarette excise } \\
\text { tax rate }\end{array}$ & $0.0114^{\star * *}(0.000128)$ & $0.0115^{* * *}(0.000123)$ & $0.0111^{* * *}(0.000117)$ & $0.0114^{* * *}(0.000124)$ & $0.0111^{* * *}(0.000117)$ & $0.0111^{* * *}(0.000117)$ & $0.0114^{* * *}(0.000128)$ \\
\hline MPL-component & $0.00624(0.0311)$ & $0.341^{* * *}(0.0303)$ & $0.337^{* * *}(0.0469)$ & $-0.0271(0.0387)$ & $0.337^{* * *}(0.0469)$ & $-0.337^{* * *}(0.0469)$ & $-0.00624(0.0311)$ \\
\hline Observations & 600 & 600 & 600 & 600 & 600 & 600 & 600 \\
\hline$R^{2}$ & 0.931 & 0.938 & 0.934 & 0.931 & 0.934 & 0.934 & 0.931 \\
\hline
\end{tabular}

Robust SEs in parentheses.

${ }^{* * *} p<0.01,{ }^{* *} p<0.05,{ }^{*} p<0.1$.

Promotion Variables Applied Pre-Sale (Trade Discount Used to Reduce Base Cost+Trade Discount Definition Includes Buydowns+State Permits Distributors to Meet Competitor Pricing+State Restricts Meeting of Competitor Pricing).

Promotions Applied at Sale (Coupons May Reduce Price Below Cost+Number of Parties Distributing Below-Cost Coupons to Consumer+Below-Cost Combination Sales Allowed+Restrictions on Below-Cost Combination Sales). 
specifications with the exception of one (allowing below-cost combination sales). This is most likely due to the fact that this variable is almost perfectly correlated with the MPL variable, and hence affected the association between prices and MPLs.

In terms of the specific MPL components, we found that states that prohibit below-cost combination sales, states that do not allow any distributing party to use trade discounts to reduce the base cost of cigarettes and states that prohibit distributing parties from meeting the price of a competitor all had higher cigarettes prices than states without such MPL components. The results suggest that the per pack cigarette price was about 30 cents higher, above and beyond the impact of MPLs, in states with those components. Other MPL components were found to be either negatively associated with cigarette prices or not significantly associated with price. For some components, such as the number of parties regulated and applying cartage to the base cost, the negative association offsets the positive association between MPLs and cigarette prices.

Table 3 presents the sensitivity analyses examining the association between cigarette prices and MPLs in 22 Nielsen markets (ie, the 19 entirely within-state markets and the 3 markets with at least $80 \%$ of the population located within a single state). The results were similar to those presented in table 2 . A notable difference is that there is now a positive and significant association between having restrictions on promotions applied at sale (prohibit coupon use to reduce cost, prohibit distributing below-cost coupons to the consumer and/or prohibit combination sales) and cigarette prices. Not shown in the paper, the sensitivity analyses that include all 52 Nielsen markets revealed no statistical significant relationship between MPLs and cigarette prices.

Table 4 presents the results that show the association between cigarette prices and MPLs/MPL components using TUS-CPS data. Similar to the results using Nielsen data, the presence of MPLs was positively associated with self-reported cigarette prices in the majority of model specifications. The results that were significant indicate that self-report per pack cigarette prices in states with MPLs were 8-34 cents higher than those without MPLs, representing a 2-8\% increase in cigarette prices. In terms of the MPL components, the total markup rates were found to be positively associated with cigarette price as well; in particular, states that had total markup rates $>24 \%$ were associated with 53 cents higher cigarette prices, representing a $12 \%$ price increase. In addition, states that prohibit below-cost combination sales and states prohibiting the distribution of below-cost coupons to the consumer had higher cigarette prices compared to states that did not. Other MPL components were found to be either negatively associated with cigarette prices or not significantly associated with price.

\section{DISCUSSION}

MPLs have been proposed to counteract the tobacco industry's price-reducing strategies in the context of the industry's massive promotional and marketing spending. ${ }^{5}$ In the 10 years in the first decade of this century, cigarette manufacturers' annual spending on price-reducing promotions and other price-reducing mechanisms, whose sole purpose is to reduce the real costs smokers pay for cigarettes, more than doubled to $\$ 6.72$ billion in 2010 , accounting for more than $80 \%$ of all promotional expenditures by the industry. ${ }^{20}$ However, until now, the empirical evidence on the effectiveness of MPLs in raising cigarette prices has been limited. In fact, previous studies found either no difference in prices between states with MPLs and states without, ${ }^{17}$ or the prices were lower in states with MPLs compared to states without MPLs. ${ }^{18}$
In this study, we examine the association between the presence of MPLs and major components within MPLs in a state and cigarette prices. Our results provide the strongest and most comprehensive evidence until now on the impact of MPLs on cigarette prices. We found that the presence of MPLs in a state was associated with a $5-11 \%$ increase in prices for low-priced cigarettes, as well as with a 3-9\% increase in median cigarette price. In addition, we also found that cigarette prices were higher, above and beyond the higher prices resulting from MPLs, in states that prohibit below-cost combination sales; do not allow any distributing party to use trade discounts to reduce the base cost of cigarettes; prohibit distributing parties from meeting the price of a competitor, and prohibit distributing below-cost coupons to the consumer. Moreover, we found that states that had a total markup rate $>24 \%$ were associated with significantly higher ( $12 \%$ increase in) cigarette prices.

Our study differs from the previous studies in several key aspects. First, while previous studies examined the association between MPLs and average cigarette prices, we focused on the prices for low-priced cigarettes. If MPLs indeed had an intended impact on increasing cigarette prices, their impact would be most pronounced at the low price end. Second, unlike Tynan et al, ${ }^{18}$ who included all 52 Nielsen markets in their analysis, we only focus on 19 Nielsen markets that fall completely within state boundaries. Since most Nielsen markets cross state boundaries, including all markets in the analysis most likely resulted in a significant measurement error in cigarette prices and biased the results. In fact, in the sensitivity analyses we conducted including all 52 Nielsen markets, we did not find any significant relationship between MPLs and cigarette prices. Third, unlike previous studies of MPLs, which primarily focused on statutes, the MPLs used in our analysis also include key information found in regulations, revenue notices, case law and AG opinions. Kentucky, for example, had an MPL that was invalidated by AG opinion, but was erroneously identified as having MPL in previous studies. Hawaii was marked as a non-MPL state in previous studies, where its general pricing laws were included in our study based on tobacco application via case law. Most importantly, we examined the presence of MPLs, and also analysed the association between major MPL components and cigarette prices, which can help researchers and policymakers identify the most effective mechanisms within MPLs that would increase cigarette prices. In particular, we found that the impact of MPLs can be further strengthened by prohibiting coupon distribution, competitor price matching and use of below-cost combination sales and trade discounts. In addition, by creating a statutory framework for markups and imposing a high markup rate, higher than the markup rate dictated by the free market (generally $18 \%{ }^{18}$ ), states can significantly raise the prices of cigarettes and reduce the cigarette consumption and tobacco-induced disease and mortality burden.

The results from our study suggest that MPLs have the potential to become an effective tool to mitigate the impact of the price-reducing promotions by the industry. Combined with decades of research on the effectiveness of increasing cigarette taxes, our study suggests that further increasing cigarette taxes and strengthening MPLs can both reduce the impact of the price-reducing promotions by the industry, and cigarette excise taxes and MPLs can and should be used as part of the coordinated pricing strategy. In addition, given our finding that prohibiting coupon distribution was associated with higher cigarette prices, polices such as price discount bans and coupon redemption bans, similar to those adopted in New York city, Providence and Chicago, could also be considered by other cities and 
Table 3 Association between cigarette price and minimum price laws: results from Nielsen Retail Scanner Data 2007-2014 (22 markets)

\section{5th price centile}

\begin{tabular}{|c|c|c|c|c|c|c|c|}
\hline & (1) & (2) & (3) & (4) & (5) & (6) & (7) \\
\hline Variables & Baseline result & $\begin{array}{l}\text { Number of parties } \\
\text { regulated }>1\end{array}$ & $\begin{array}{l}\text { Total markup across } \\
\text { standard distribution }\end{array}$ & Cartage applied to base cost & $\begin{array}{l}\text { Any taxes applied to } \\
\text { base cost }\end{array}$ & $\begin{array}{l}\text { Other fees applied to } \\
\text { base cost }\end{array}$ & $\begin{array}{l}\text { State does not allow } \\
\text { coupons }\end{array}$ \\
\hline Minimum pricing law & $0.324^{* * *}(0.0285)$ & $0.445^{* * *}(0.0301)$ & $0.593^{* * *}(0.0437)$ & $0.363^{* * *}(0.0290)$ & $0.509^{* * *}(0.0305)$ & $0.304^{* * *}(0.0301)$ & $0.367^{* * *}(0.0291)$ \\
\hline $\begin{array}{l}\text { State cigarette excise } \\
\text { tax rate }\end{array}$ & $0.00963^{* * *}(0.000296)$ & $0.0103^{* * *}(0.000362)$ & $0.00961^{* * *}(0.000292)$ & $0.00952^{* * *}(0.000296)$ & $0.0101 * * *(0.000288)$ & $0.00957^{* * *}(0.000303)$ & $0.0100 * * *(0.000254)$ \\
\hline MPL-component & & $-0.264^{* * *}(0.0426)$ & $-0.147^{* * *}(0.0169)$ & $-0.405^{* * *}(0.0274)$ & $-0.361^{* * *}(0.0319)$ & $0.134^{* * *}(0.0459)$ & $-0.249^{* * *}(0.0538)$ \\
\hline Observations & 696 & 696 & 696 & 696 & 696 & 696 & 696 \\
\hline \multirow[b]{3}{*}{ Variables } & 0.882 & 0.887 & 0.889 & 0.887 & 0.894 & 0.883 & 0.886 \\
\hline & (9) & (10) & (11) & (12) & (13) & (14) & (15) \\
\hline & $\begin{array}{l}\text { Consumers cannot receive } \\
\text { below-cost coupon }\end{array}$ & $\begin{array}{l}\text { Below-cost combination } \\
\text { sales not allowed }\end{array}$ & $\begin{array}{l}\text { Trade discounts may not } \\
\text { be used }\end{array}$ & $\begin{array}{l}\text { Trade discount definition does } \\
\text { not include buy downs, etc }\end{array}$ & $\begin{array}{l}\text { Parties may not meet } \\
\text { competitor pricing }\end{array}$ & $\begin{array}{l}\text { Promotion restrictions } \\
\text { applied pre-sale }\end{array}$ & $\begin{array}{l}\text { Promotion restrictions } \\
\text { applied at sale }\end{array}$ \\
\hline Minimum pricing law & $0.367^{* * *}(0.0291)$ & $0.148^{* * *}(0.0355)$ & $0.292^{* * *}(0.0287)$ & $0.585^{* * *}(0.0604)$ & $0.292^{* * *}(0.0287)$ & $0.863^{* * *}(0.0617)$ & $0.118^{* *}(0.0553)$ \\
\hline $\begin{array}{l}\text { State cigarette excise } \\
\text { tax rate }\end{array}$ & $0.0100^{* * *}(0.000254)$ & $0.00960 * * *(0.000298)$ & $0.00931 * * *(0.000305)$ & $0.00955^{* * *}(0.000300)$ & $0.00931^{* * *}(0.000305)$ & $0.00931^{* * *}(0.000305)$ & $0.0100 * * *(0.000254)$ \\
\hline MPL-component & $-0.249^{* * *}(0.0538)$ & $0.213^{* * *}(0.0347)$ & $0.570^{* * *}(0.0589)$ & $-0.280^{* * *}(0.0582)$ & $0.570^{* * *}(0.0589)$ & $-0.570^{* * *}(0.0589)$ & $0.249^{* * *}(0.0538)$ \\
\hline Observations & 696 & 696 & 696 & 696 & 696 & 696 & 696 \\
\hline$R^{2}$ & 0.886 & 0.885 & 0.892 & 0.885 & 0.892 & 0.892 & 0.886 \\
\hline \multicolumn{8}{|l|}{ 50th price centile } \\
\hline & (1) & (2) & (3) & (4) & (5) & (6) & (7) \\
\hline Variables & Baseline Result & $\begin{array}{l}\text { Number of Parties } \\
\text { Regulated }>1\end{array}$ & $\begin{array}{l}\text { Total Markup Across } \\
\text { Standard Distribution }\end{array}$ & Cartage Applied to Base Cost & $\begin{array}{l}\text { Any Taxes Applied to } \\
\text { Base Cost }\end{array}$ & $\begin{array}{l}\text { Other Fees Applied to } \\
\text { Base Cost }\end{array}$ & $\begin{array}{l}\text { State Does Not Allow } \\
\text { Coupons }\end{array}$ \\
\hline Minimum pricing law & $0.246^{* * *}(0.0267)$ & $0.406^{* * *}(0.0298)$ & $0.515^{* * *}(0.0419)$ & $0.294^{* * *}(0.0268)$ & $0.466^{* * *}(0.0295)$ & $0.232^{* * *}(0.0287)$ & $0.286^{* * *}(0.0283)$ \\
\hline $\begin{array}{l}\text { State cigarette excise } \\
\text { tax rate }\end{array}$ & $0.0100^{* * *}(0.000260)$ & $0.0109 * * *(0.000317)$ & $0.0100^{* * *}(0.000256)$ & $0.00991 * * *(0.000260)$ & $0.0107^{* * *}(0.000249)$ & $0.0100 * * *(0.000266)$ & $0.0104^{* * *}(0.000222)$ \\
\hline MPL-component & & $-0.347^{* * *}(0.0418)$ & $-0.147^{* * *}(0.0170)$ & $-0.495^{* * *}(0.0310)$ & $-0.428^{* * *}(0.0319)$ & $0.0949 * *(0.0420)$ & $-0.227^{* * *}(0.0490)$ \\
\hline Observations & 696 & 696 & 696 & 696 & 696 & 696 & 696 \\
\hline \multirow[b]{3}{*}{ Variables } & 0.904 & 0.911 & 0.910 & 0.911 & 0.919 & 0.904 & 0.907 \\
\hline & (9) & (10) & (11) & (12) & (13) & (14) & (15) \\
\hline & $\begin{array}{l}\text { Consumers Cannot Receive } \\
\text { Below-Cost Coupon }\end{array}$ & $\begin{array}{l}\text { Below-Cost Combination } \\
\text { Sales Not Allowed }\end{array}$ & $\begin{array}{l}\text { Trade Discounts May Not } \\
\text { Be Used }\end{array}$ & $\begin{array}{l}\text { Trade Discount Definition Does } \\
\text { Not Include Buy Downs, etc }\end{array}$ & $\begin{array}{l}\text { Parties May Not Meet } \\
\text { Competitor Pricing }\end{array}$ & $\begin{array}{l}\text { Promotion Restrictions } \\
\text { Applied Pre-Sale }\end{array}$ & $\begin{array}{l}\text { Promotion Restrictions } \\
\text { Applied at Sale }\end{array}$ \\
\hline Minimum pricing law & $0.286^{* * *}(0.0283)$ & $0.0439(0.0349)$ & $0.215^{* * *}(0.0269)$ & $0.426^{* * *}(0.0557)$ & $0.215^{* * *}(0.0269)$ & $0.780^{* * *}(0.0554)$ & $0.0585(0.0481)$ \\
\hline $\begin{array}{l}\text { State cigarette excise } \\
\text { tax rate }\end{array}$ & $0.0104^{* * *}(0.000222)$ & $0.0100 * * *(0.000262)$ & $0.00973^{* * *}(0.000265)$ & $0.00999 * * *(0.000264)$ & $0.00973^{* * *}(0.000265)$ & $0.00973^{* * *}(0.000265)$ & $0.0104^{* * *}(0.000222)$ \\
\hline MPL-component & $-0.227^{* * *}(0.0490)$ & $0.245^{* * *}(0.0364)$ & $0.565^{* * *}(0.0540)$ & $-0.193^{* * *}(0.0551)$ & $0.565^{* * *}(0.0540)$ & $-0.565^{* * *}(0.0540)$ & $0.227^{* * *}(0.0490)$ \\
\hline Observations & 696 & 696 & 696 & 696 & 696 & 696 & 696 \\
\hline$R^{2}$ & 0.907 & 0.907 & 0.913 & 0.905 & 0.913 & 0.913 & 0.907 \\
\hline
\end{tabular}

Robust SEs in parentheses.

${ }^{* * *} \mathrm{p}<0.01,{ }^{* *} \mathrm{p}<0.05,{ }^{*} \mathrm{p}<0.1$

Promotion Variables Applied Pre-Sale (Trade Discount Used to Reduce Base Cost+Trade Discount Definition Includes Buydowns+State Permits Distributors to Meet Competitor Pricing+State Restricts Meeting of Competitor Pricing).

Promotions Applied at Sale (Coupons May Reduce Price Below Cost+Number of Parties Distributing Below-Cost Coupons to Consumer+Below-Cost Combination Sales Allowed+Restrictions on Below-Cost Combination Sales).

Control Variables not Shown: Quarter and Year Fixed Effects. 
Table 4 Association between cigarette price and minimum price laws: results from TUS-CPS

\begin{tabular}{|c|c|c|c|c|c|c|c|c|}
\hline & (1) & (2) & (3) & (4) & (5) & (6) & (7) & (8) \\
\hline Variables & Baseline result & $\begin{array}{l}\text { Number of parties } \\
\text { regulated }>1\end{array}$ & $\begin{array}{l}\text { Total markup across } \\
\text { standard distribution }\end{array}$ & $\begin{array}{l}\text { Total markup across } \\
\text { standard distribution } \\
\text { (Categorical) }\end{array}$ & $\begin{array}{l}\text { Cartage applied to } \\
\text { base cost }\end{array}$ & $\begin{array}{l}\text { Any taxes applied } \\
\text { to base cost }\end{array}$ & $\begin{array}{l}\text { Other fees applied } \\
\text { to base cost }\end{array}$ & $\begin{array}{l}\text { State does not } \\
\text { allow coupons }\end{array}$ \\
\hline $\begin{array}{l}\text { Minimum pricing } \\
\text { law }\end{array}$ & $0.0908^{* * *}(0.0335)$ & $0.345^{* * *}(0.0614)$ & $-0.0167(0.0485)$ & $0.0337(0.0541)$ & $0.129 * * *(0.0385)$ & $0.341^{* * *}(0.0522)$ & $0.125^{* * *}(0.0339)$ & $0.0866^{* *}(0.0346)$ \\
\hline $\begin{array}{l}\text { State cigarette } \\
\text { excise tax rate }\end{array}$ & $0.00996^{* * *}(0.000219)$ & $0.0105^{* * *}(0.000224)$ & $0.00992^{* * *}(0.000220)$ & $0.00989^{* * *}(0.000221)$ & $0.00996^{* * *}(0.000219)$ & $0.0101^{* * *}(0.000220)$ & $\begin{array}{l}0.00990^{* * *} \\
(0.000214)\end{array}$ & $\begin{array}{l}0.00991^{* * *} \\
(0.000218)\end{array}$ \\
\hline MPL-component & & $-0.360^{* * *}(0.0620)$ & $0.0518^{* * *}(0.0175)$ & & $-0.0958^{* *}(0.0390)$ & $-0.329^{* * *}(0.0511)$ & $-0.110^{* *}(0.0463)$ & $0.0285(0.0439)$ \\
\hline Total markup 0-6\% & & & & $-0.323^{* * *}(0.0954)$ & & & & \\
\hline $\begin{array}{l}\text { Total markup 6- } \\
12 \%\end{array}$ & & & & $0.0705(0.0547)$ & & & & \\
\hline $\begin{array}{l}\text { Total markup 12- } \\
18 \%\end{array}$ & & & & $-0.00567(0.0597)$ & & & & \\
\hline Total markup $>24 \%$ & & & & $0.529 * * *(0.112)$ & & & & \\
\hline Observations & 49548 & 49548 & 49548 & 49548 & 49548 & 49548 & 49548 & 49548 \\
\hline \multirow[b]{3}{*}{ Variables } & 0.146 & 0.147 & 0.146 & 0.146 & 0.146 & 0.147 & 0.146 & 0.146 \\
\hline & (9) & (10) & (11) & (12) & (13) & (14) & (15) & \\
\hline & $\begin{array}{l}\text { Consumers cannot } \\
\text { receive below-cost } \\
\text { coupon }\end{array}$ & $\begin{array}{l}\text { Below-cost } \\
\text { combination sales not } \\
\text { allowed }\end{array}$ & $\begin{array}{l}\text { Trade discounts may } \\
\text { not be used }\end{array}$ & $\begin{array}{l}\text { Trade discount definition } \\
\text { does not include buy downs, } \\
\text { etc }\end{array}$ & $\begin{array}{l}\text { Parties may not meet } \\
\text { competitor pricing }\end{array}$ & $\begin{array}{l}\text { Promotion variables } \\
\text { applied pre-sale }\end{array}$ & $\begin{array}{l}\text { Promotions } \\
\text { applied at sale }\end{array}$ & \\
\hline $\begin{array}{l}\text { Minimum pricing } \\
\text { law }\end{array}$ & $0.0774^{* *}(0.0346)$ & $-0.0215(0.0436)$ & $0.136^{* * *}(0.0350)$ & $0.0823(0.0591)$ & $0.0972^{* * *}(0.0326)$ & $0.0161(0.0943)$ & $0.110^{* *}(0.0486)$ & \\
\hline $\begin{array}{l}\text { State cigarette } \\
\text { excise tax rate }\end{array}$ & $0.00981 * * *(0.000218)$ & $0.00993^{* * *}(0.000220)$ & $0.00991^{* * *}(0.000217)$ & $0.00996^{* * *}(0.000220)$ & $0.00995^{* * *}(0.000218)$ & $\begin{array}{l}0.00994^{* * *} \\
(0.000216)\end{array}$ & $\begin{array}{l}0.00992^{* * *} \\
(0.000218)\end{array}$ & \\
\hline MPL-component & $0.0825^{*}(0.0437)$ & $0.145^{* * *}(0.0436)$ & $-0.149^{* * *}(0.0464)$ & $0.00943(0.0562)$ & $-0.0575(0.0853)$ & $0.0839(0.0905)$ & $-0.0220(0.0445)$ & \\
\hline Observations & 49548 & 49548 & 49548 & 49548 & 49548 & 49548 & 49548 & \\
\hline$R^{2}$ & 0.146 & 0.146 & 0.146 & 0.146 & 0.146 & 0.146 & 0.146 & \\
\hline
\end{tabular}

\section{Robust SEs in parentheses.}

${ }^{* * *} p<0.01,{ }^{* *} p<0.05,{ }^{*} p<0.1$

Promotion Variables Applied Pre-Sale (Trade Discount Used to Reduce Base Cost+Trade Discount Definition Includes Buydowns+State Permits Distributors to Meet Competitor Pricing+State Restricts Meeting of Competitor Pricing).

(Coupons May Reduce Price Below Cost+Number of Parties Distributing Below-Cost Coupons to Consumer+Below-Cost Combination Sales Allowed+Restrictions on Below-Cost Combination Sales).

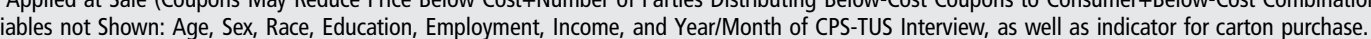


localities to counteract the tobacco industry's's price-reducing tactics, particularly in states without MPLs or states with MPLs but do not prohibit distributing below-cost coupons to the consumer.

Our findings should be viewed in the context of the following limitations. First, the MPLs were based on state-level codified law; other state policy instruments, including session laws (except for effective date verification), legislative bills, state constitutions and non-codified policies, were excluded. Similarly, laws pertaining to enabling direct sales, master settlement agreements or other non-tax issues were considered beyond the scope of this study and were not included in collection. Implementation or actual enforcement of these pricing laws (where not explicitly applied within the scope of collection) was beyond the scope of this study. Second, since there was virtually no within-state variation in MPLs during our study period, we were unable to identify the causal impact of MPLs on cigarette prices using the change in MPLs overtime within a state. Additionally, we were also limited by the number of Nielsen markets with which we could work in our analysis.

Despite these limitations, our study provides strong evidence to support recent calls for reducing tobacco use and access through adopting and strengthening MPLs. ${ }^{5}$ In addition, policymakers who seek to strengthen MPLs can also do so by imposing high markup rates and by regulating the distribution of coupons, preventing wholesalers or retailers from providing them directly to consumers, as well as prohibiting combination or multipack sales, restricting competitor price matching and trade discounts.

\section{What this paper adds}

- This study examines the association between minimum markup/price laws (MPLs) and cigarette prices, focusing on the association between MPLs and low-priced cigarettes, and the impact of the major MPL components.

- We found that MPLs were associated with higher cigarette prices and that certain components of MPLs, such as markup rates and restrictions on distributing coupons, competitor price matching and prohibition of below-cost combination sales and trade discounts, are particularly effective in increasing cigarette prices.

Twitter Follow Jidong Huang at @JidongHuang and Jamie Chriqui at @jfchriqui

Contributors FJC, JFC and JH designed the study. JFC, HD, MCD and MM collected the data. JH, MCD and MM conducted data analysis. FJC, JFC and HD contributed to data interpretation. JH and HD wrote the first draft. FJC and JFC revised the draft. The final version of this paper has been reviewed and approved by all coauthors.

Funding This work was supported by a grant from the US National Cancer Institute at the National Institutes of Health (Grant number 1U01CA154248), entitled 'Monitoring and Assessing the Impact of Tax and Price Policies on U.S. Tobacco Use.' None of the funding agencies played any role in study design; in the collection, analysis and interpretation of data; in the writing of the report; and in the decision to submit the article for publication. The opinions expressed here are those of the authors, and do not necessarily reflect those of the sponsors.
Competing interests None declared.

Provenance and peer review Not commissioned; externally peer reviewed.

Open Access This is an Open Access article distributed in accordance with the Creative Commons Attribution Non Commercial (CC BY-NC 4.0) license, which permits others to distribute, remix, adapt, build upon this work non-commercially, and license their derivative works on different terms, provided the original work is properly cited and the use is non-commercial. See: http://creativecommons.org/ licenses/by-nc/4.0/

\section{REFERENCES}

1 International Agency for Research on Cancer. IARC handbooks of cancer prevention, tobacco control, vol. 14. Effectiveness of tax and price policies for tobacco control. Lyon: IARC, 2011.

2 Slater SJ, Chaloupka FJ, Wakefield M, et al. The impact of retail cigarette marketing practices on youth smoking uptake. Arch Pediatr Adolesc Med 2007; 161:440-5.

3 Henriksen L, Schleicher NC, Dauphinee AL, et al. Targeted advertising, promotion, and price for menthol cigarettes in California high school neighborhoods. Nicotine Tob Res 2012;14:116-21.

4 HHS. Preventing Tobacco Use Among Youth and Young Adults: a report of the Surgeon General. 2012. http://www.surgeongeneral.gov/library/reports/ preventing-youth-tobacco-use/full-report.pdf (accessed 18 Mar 2016).

5 McLaughlin I, Pearson A, Laird-Metke E, et al. Reducing tobacco use and access through strengthened minimum price laws. Am J Public Health 2014; 104:1844-50.

6 Golden SD, Smith MH, Feighery EC, et al. Beyond excise taxes: a systematic review of literature on non-tax policy approaches to raising tobacco product prices. Tob Control 2016:25:377-85.

7 Centers for Disease Control and Prevention (CDC). State cigarette minimum price laws_United States, 2009. MMWR Morb Mortal Wkly Rep 2010;59:389-92.

8 Mohl B. At Some Vendors, Cost of Cigarettes Rises As State Enforces Pricing Law. http://archive.boston.com/business/globe/articles/2003/10/18/at_some_vendors cost_of_cigarettes_rises_as_state_enforces_pricing_law/ (accessed 18 Mar 2016).

9 Kurt R. Appendix A: findings model legislatoin establishing a minimum retail sales price for cigarettes [and Other Tobacco Products]. ChangeLab Solutions, 2013.

10 Peggy M. Effect of California state tax increase on consumption per day, quitting rates and packings smoked, 1988-89 (1st three quarters). 1990. http://www. pmdocs.com/core/downloadSearchBlob?IDX=1\&FROM=SEARCH\&CVSID = d14581cf42cfdbe592157961e0020045 (accessed 18 Mar 2016).

11 Tauras JA, Peck RM, Chaloupka FJ. The role of retail prices and promotions in determining cigarette brand market shares. Rev Ind Organ 2006;28:253-84.

12 Chaloupka FJ, Cummings KM, Morley CP, et al. Tax, price and cigarette smoking: evidence from the tobacco documents and implications for tobacco company marketing strategies. Tob Control 2002;11(Suppl 1):162-72.

13 NY Department of Taxation and Finance. Cigarette Manufacturers' Promotional Programs and the Cigarette Marketing Standards Act. 2000. https://www.tax.ny. gov/pdf/memos/cigarette/m00_2m.pdf (accessed 18 Mar 2016).

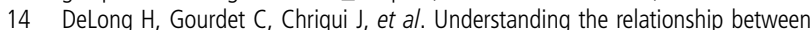
state minimum pricing laws and discount mechanisms, 2005-2014. Poster session presented at: Society for Research on Nicotine and Tobacco 21st Annual Meeting; Philadelphia, PA, 2015

15 E\&H Wholesale, Inc. v. Glaser Bros., 158 Cal. App. 3d 728 (Ct. App. 1984); Island Tobacco Co. v. R. J. Reynolds Tobacco Co., 63 Haw. 289 (1981); Dikeou v.Food Distributors Ass'n, 107 Colo. 38 (1940).

16 Tobacco Control Legal Consortium. Cigarette Minimum Price Laws. 2011. http://publichealthlawcenter.org/sites/default/files/resources/tclc-guidecigminimumpricelaws-2011.pdf (accessed 16 Mar 2016).

17 Feighery EC, Ribisl KM, Schleicher NC, et al. How do minimum cigarette price laws affect cigarette prices at the retail level? Tob Control 2005;14:80-5.

18 Tynan MA, Ribisl KM, Loomis BR. Impact of cigarette minimum price laws on the retail price of cigarettes in the USA. Tob Control 2013;22:e78-85.

19 Michael J. The unfair cigarette sales act. Information Brief Minnesota House of Representatives Research Department, 2000. http://www.leg.state.mn.us/docs/ pre2003/other/000646.pdf (accessed 24 Mar 2016).

20 Berman M, Snyder KM. Tobacco price promotion local regulation of discount coupons and certain value-added sales. Center for Public Health and Tobacco Policy. http://www.tobaccopolicycenter.org/documents/Price\%20Promotion\%20Local \%20Regulation\%20FINAL.pdf (accessed 18 Mar 2016). 